\title{
KERAGAMAN FENOTIPE DAN GEN SIFAT KUALITATIF PADA AYAM KAMPUNG
}

\author{
Diversity of Fenotepe and Gene to Qualitative Traits of Kampung Chickens \\ 1Sirman Kunuti, ${ }^{* 1}$ Safriyanto Dako, dan ${ }^{2}$ Fahrul Ilham \\ 1Jurusan Peternakan Fakultas Pertanian Universitas Negeri Gorontalo \\ ${ }^{2}$ Fakultas Peternakan Universitas Brawijaya \\ *Coresponding Authors: email: sdako@ung.ac.id
}

\begin{abstract}
The research objective was to determine the phenotypic diversity of the qualitative characteristics of Kampung chickens. This research uses a descriptive statistic method. A total of 300 adult (unsex) chickens aged 6 months were used for this study. Qualitative characteristics include: color feather, color pattern, comb shape, fliker, and color variations. The results showed that the gene frequencies of colored feathers and colorless feathers from Kampung chickens were $0.96 \%$ and 0,04 . The gene frequencies for the color feather pattern were $0.61,0.43$, and 0,03 for the columbian, wild and black color patterns. The gene frequencies for striated and plain hair were: 0.29 and 0.71 . The gene frequencies for silver and gold feathers are 0.30 , and $0.71 \%$. The Gene Frequencies for Single Comb and Pae are 0.60 and 0.40 . The phenotypic frequency of the color pattern of the Kampung chickens was $43.33 \%, 38.00 \%$, and $12.00 \%$, for wild, Columbia and black pattern. Phenotypic frequency of lurik and plan were: $81.34 \%$ and $18.66 \%$. The phenotypic frequency of silver and gold feather were $31,89 \%$, and $68.11 \%$. The phenotypic frequencies of the comb shape single, pea, rose, and walnuts were $36 \%$, $27,82 \%, 18,51 \%$ dan $17,67 \%$. The population of Paguyaman chickens has a phenotype of colored feathers, the color feather pattern are wild, single comb, yellow shank color, and these characteristics are dominant compared to other characteristics.
\end{abstract}

Key words: Qualitative traits, Native chicken, and frequency of feather color

\section{ABSTRAK}

Tujuan penelitian adalah untuk mengetahui keragaman fenotipik karakteristik kualitatif ayam kampung. Penelitian ini menggunakan metode statistic deskriptif. Sebanyak 300 ekor ayam dewasa (unsex) berumur 6 bulan digunakan untuk penelitian ini. Ciri kualitatif meliputi: warna bulu, corak, bentuk sisir, kedipan dan variasi warna. Hasil penelitian menunjukkan bahwa frekuensi gen bulu berwarna dan bulu tidak berwarna dari ayam buras adalah 0,96\% dan 0,04. Frekuensi gen untuk pola warna bulu adalah $0.61,0.43$, dan 0.03 , untuk pola warna columbian, wild dan black. Frekuensi gen untuk bulu lurik dan polos adalah: 0,29 dan 0,71. Frekuensi gen untuk bulu perak dan emas adalah 0,30, dan 0,71\%. Frekuensi Gen untuk jengger tunggal, dan Pae adalah 0,60 dan 0,40. Frekuensi fenotipe pola warna ayam kampung adalah $43,33 \%, 38,00 \%$, dan $12,00 \%$, untuk pola warna liar, columbian dan hitam. Frekuensi fenotipe lurik dan polos adalah: $81,34 \%$ dan 18,66\%. Frekuensi fenotipe bulu perak dan emas adalah $31,89 \%$, dan $68,11 \%$. Frekuensi fenotipe bentuk jengger tunggal, Pea, Ros, dan Walnut masing-masing; 36\%, 27,82\%, 18,51\% dan 17,67\%. Karaketeristik ayam Paguyaman memiliki fenotipe bulu berwarna, dengan corak warna bulu: liar, jengger tunggal, warna shank kuning, dan ciri-ciri tersebut dominan dibandingkan ciri lainnya.

Kata kunci: Sifat kualitatif, ayam kampung, dan frekuensi warna bulu

Cara Mengutip (APA Citation Style)

Kunuti, S., Dako, S., dan Ilham, F. 2021. Keragaman Fenotipe dan Gen Sifat Kualitatif pada Ayam Kampung. Jambura Journal of Animal Science, 3(2),87-95

(C) 2021 - Kunuti, S., Dako, S., dan Ilham, F. Under the license CC BY-NC 4. 


\section{PENDAHULUAN}

Perkembangan usaha ternak unggas khusus ayam ras di Indonesia sangat pesat,sedangkan untuk usaha ayam kampung masih sangat terbatas, terutama ditingkat peternak. Sistim pemeliharaan ayam Kampung di Provinsi Gorontalo bersifat tradisional dan semi intensif, terutama masyarakat peternak yang tinggal diwilayah pedesaan, sedangkan peternak memelihara secara intensif (skala usaha menengah-kecil) masih sangat terbatas (sedikit). Penggunaan bibit ayam kampung untuk usaha menegah masih sangat terbatas jumlahnya, sehingga mempengaruhi keberlangsungan usaha. Penanganan usaha ayam kampung secara komersial banyak mengalami kendala terutama dari produksi dan reproduksi. Penyebab utama adalah mutu genetic dari ayam kampung yang rendah. Lambatnya pertumbuhan dan variasi produksi telur, menyebabkan sulitnya memperoleh bibit yang berkesinambungan, dan adanya faktor penyakit musiman. (Sartika, 2016; Sumantri, 2020). Upaya pengembangan ayam kampung melalui usaha pembibitan ayam kampung didaerah dapat dilakukan, sehingga dapat digunakan untuk meningkatkan genetic dari ayam Kampung., namun ketersediaan data tentang ayam kampung didaerah masih sebatas kuantitas, sedangkan informasi keragaman sifat genetik ayam kampung yang bernilai ekonomis (meliputi sifat kualitatif dan kuantitatif) belum
memadai.Informasi sifat kualitatif dan kuantitatif sangat diperlukan dalam penerapan program pemuliaan yang terarah untuk meningkatkan produktivitas sifat tersebut. Sifat kualitatif berhubungan dengan status fisiologi dan adaptasi ternak terhadap habitatnya. Tampilan sifat kulalitatif merupakan gambaran adaptasi ternak terhadap lingkungan. Sifat kualitatif ayam Kampung baik jantan dan betina sangat bervariasi (Subekti dan Arlina 2011)., sedangkan perkawinan silang dan seleksi akan memepengaruhi keseimbangan sifat kualitatif ayam kampung (Dako, et al, 2020). Tujuan penelitian ini untuk mengetahui keragaman fenotipe sifat kualitatif ayam kampung

\section{METODOLOGI PENELITIAN}

Sebanyak 300 ekor ayam kampung umur 6 bulan (unseks). Ayam-ayam ini dikoleksi dari Kecamatan Paguyaman Kabupaten Boalemo. Penelitian ini menggunakan metode statistik deskriptif. Fokus pengukuran sifat kualitatif pada ayam kampung berdasarkan pengelompokkan sifat Warna bulu dan pola warna bulu, Kerlib bulu, corak bulu, warna shank, dan bentuk jengger mengikuti petunjuk Saleh, dkk (2020); Bugiwati, dkk (2020):

\section{Analisis Data}

Analisis frekuensi fenotip suatu sifat ayam kampung mengikuti saran (Noor R, 2008; Dako, dkk 2019).

Keterangan:

$\mathrm{FF}=$ Frekuensi Fenotip

\section{Frekuensi Gen Terpaut Kelamin}

Frekuensi gen dominan terpaut kromosom kelamin untuk corak bulu, kerlip bulu dan warna shank yang merupakan gen terpaut kelamin dihitung dengan menggunakan rumus (Nishida et al. 1980

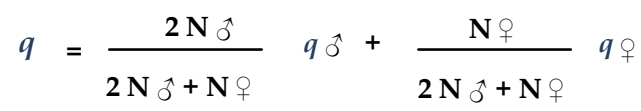

Keterangan :

$\mathrm{q} \hat{o}=$ frekuensi gen dominan pada jantan

$\mathrm{N}_{\hat{0}}=$ jumlah total individu jantan

$\mathrm{q}+$ = frekuensi gen dominan pada betina

$\mathrm{N} \bigcirc$ = jumlah total individu betina 


\section{Frekuensi gen alel ganda}

Menghitung populasi ayam kampung memiliki 4 pola warna bulu atau lebih, maka perhitungan frekuensi gen pola warna bulu yang merupakan alel ganda maka dihitung mengikuti saran Dako, et al, (2020) dengan rumus : $(p+q+r+\ldots+s)=1$, dimana $\mathrm{q}, \mathrm{r}$ dan $\mathrm{s}$ adalah alel pola warna yang ditemukan

Keterangan :

$\mathrm{p}=$ frekuensi gen $\mathrm{E}$;

$\mathrm{q}=$ frekuensi gen $\mathrm{e}^{+}$

$\mathrm{r}=$ frekuensi gen $\mathrm{e}^{\mathrm{b}}$; dan

$\mathrm{s}=$ frekuensi gen $\mathrm{e}$

HASIL DAN PEMBAHASAN

Frekuensi fenotipe Ayam Kampung

Frekuensi Sifat kualitatif yang warna shank, dan bentuk jengger. Hasil pengamatan fenotipe dapat dilihat pada Tabel 1.

diamati pada penelitian ini terdiri dari warna bulu, pola warna, corak, kerlip,

Tabel 1. Frekuensi Fenotip Sifat Kualitatif Ayam kampung asal Kecamatan Paguyaman

\begin{tabular}{|c|c|c|c|}
\hline \multirow[t]{2}{*}{ Fenotipe } & \multirow[t]{2}{*}{ Genotipe } & \multirow[t]{2}{*}{ Alel } & Frekuensi Fenotipe (\%) \\
\hline & & & $\mathrm{N}=300$ \\
\hline \multicolumn{4}{|l|}{ Warna Bulu } \\
\hline Tidak Berwarna & Ii & I & 6.66 \\
\hline Berwarna & ii & $\mathrm{i}$ & 93.34 \\
\hline \multicolumn{4}{|l|}{ Pola Warna } \\
\hline Hitam & E- & $\mathrm{E}$ & 12 \\
\hline Liar & $\mathrm{e}^{+-}$ & $\mathrm{e}^{+}$ & 43.33 \\
\hline Columbian & $\mathrm{e}$ & $\mathrm{e}$ & 38 \\
\hline \multicolumn{4}{|l|}{ Corak } \\
\hline Polos & B- & B & 18.66 \\
\hline Lurik & $\mathrm{Bb}$ & $\mathrm{b}$ & 81.34 \\
\hline \multicolumn{4}{|l|}{ Kerlib } \\
\hline Perak & S- & S & 30.86 \\
\hline Emas & ss & $\mathrm{s}$ & 69.14 \\
\hline \multicolumn{4}{|l|}{ Warna Shank } \\
\hline Kuning/Putih & Id- & Id & 63.66 \\
\hline Hitam/abu-abu & idid & id & 36.34 \\
\hline \multicolumn{4}{|l|}{ Bentuk Jengger } \\
\hline Pea & $\operatorname{RrPP}$ & PP & 27.82 \\
\hline Tunggal & $\operatorname{Rrpp}$ & $\mathrm{pp}$ & 36 \\
\hline Walnut & $\operatorname{RrPp}$ & $-\mathrm{rP}-$ & 17.67 \\
\hline Rose & RRpp & $-\mathrm{Rp}-$ & 18.51 \\
\hline
\end{tabular}

\section{Frekuensi Warna Bulu}

Bulu penutup tubuh unggas memiliki fungsi yang penting, terutama status fisiologi keseimbangan tubuh dan penciri utama fenotipe secara visual. Berdasarkan tabel 1 warna bulu berwarna dari ayam kampung sebesar $93.34 \%$, sedangkan tidak berwarna sebesar $6.66 \%$. Hasil ini menggambarkan ayam kampung berasal dari Kecamatan paguyaman dominan memiliki fenotipe warna bulu berwarna (ii) dan fenotipe bulu tidak berwarna bersifat resesif (Ii). Hasil ini stidak berbeda dengan yang di hasilkan oleh Edowai,(2019) Ayam kampung yang berasal dari kabupaten nabire memiliki warna bulu berwarna 95\% 
dan warna bulu tidak berwarna (putih) 5\%. Menurut Nishida et al. (1980) warna bulu putih pada ayam kampung bersifat resesif., sedangkan warna bulu pada ayam hasil silangan dari persilangan ayam broiler dan ayam kampung dihasilkan ayam yang memiliki warna bulu tidak berwarna (putih) (I) sebesar $66.20 \%$, dan bersifat dominan terhadap warna bulu berwarna (ii) sebesar 33.80\% (Dako, et al, 2020). Warna bulu ayam dipengaruhi oleh adanya pigmen melanoblast yang dibentuk saat awal embrio sekitar 8 jam inkubasi (Scanes et al. 2004).

\section{Frekuensi Variasi Warna bulu atau pola warna bulu}

Berdasarkan hasil pengamatan terhadap sifat kualitatif variasi warna bulu ayam kampung berasal dari Kecamatan Paguyaman, terlihat pada Tabel 1.

Frekuensi fenotipe pola warna bulu ayam kampung terbanyak adalah pola liar $(43.33 \%)$. Pola colombian $(38.00 \%)$, dan hitam $(12.00 \%)$ dan tidak berwarna $(6.66 \%)$. Hasil penelitian ini berbeda dengan yang di temukan oleh Amlia dkk (2016) menyatakan warna bulu ayam kampung di Kecamatan Lasimu Kabupaten Buton sebanyak 32-35\% adalah pola liar. Mansjoer (2005) menyatakan ayam kampung di Indonesia mempunyai jarak genetik yang dekat dengan ayam hutan merah Sumatera (Gallus gallus gallus), dan ayam hutan merah Jawa (Gallus gallus javanicus) daripada ayam hutan hijau (Gallus varius). Sartika (2008) ayam kampung memiliki warna yang beraneka ragam (hitam, coklat, coklat kemerahan, coklat kekuningan, putih, bintik merah dan hitam atau putih-hitam). Rendahnya frekuensi pola warna hitam disebabkan warna hitam pada ayam tidak memiliki kestabilan sehingga dapat dipengaruhi oleh pola liar. Interaksi alel ee dan $\mathrm{e}^{\mathrm{b}}$ di lokus $\mathrm{E}$ sangat besar menghambat pembentukkan ekspresi warna hitam berdasarkan uji persilangan (Saleh, dkk. 2020)

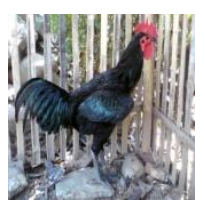

a

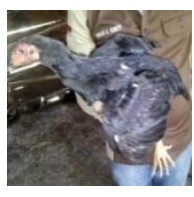

e

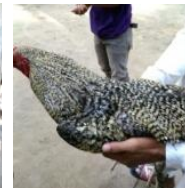

b

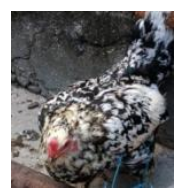

f

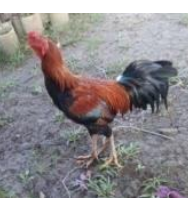

c

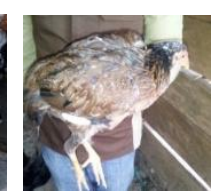

g

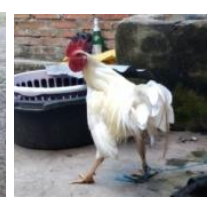

d

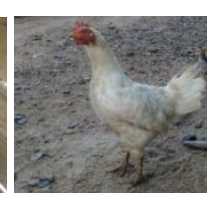

h

a: hitam, b:liar, c:colombian, d:putih (jantan)

e: hitam, f:Liar, g:colombian, h:tidak berwarna (betina)

Gambar 3. Pola bulu pada ayam kampung

\section{Frekuensi Corak Bulu}

Tabel 1 menggambarkan Tipe bulu lurik pada ayam kampung dominan terhadap corak polos. Sama halnya yang ditemukan oleh Sadarman dkk (2013) dalam penelitannya menyatakan ayam kampung yang berasal dari Desa Menaming memiliki corak lurik dominan $56 \%$.
Ferkuensi corak bulu lurik yang tinggi diakibatkan adanya persilangan antara ayam yang berasal dari luar kecamatan paguyaman, dan mungkin ayam tersebut merupakan ras lain dari ayam kampung. Menurut Dako, et al (2020) ayam hasil persilangan memiliki gen pola bulu lurik (B-) bersifat dominan tidak lengkap dan penampilannya bervariasi 
yang disebabkan oleh faktor jenis kelamin dan pertumbuhan bulu. Pada betina gen terkaitnya bersifat homozigot, sedangkan pada jantan bisa bersifat homozigot atau heterozigot. Genotip hitam dan putih pada ayam dapat memengaruhi alel $S$ dan s yang hanya dapat dibedakan melalui uji perkawinan (Sartika $d k k$. 2008).

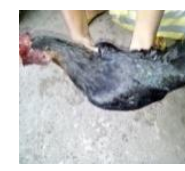

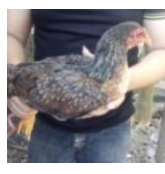

$\mathrm{b}$

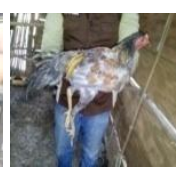

c

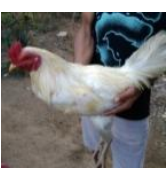

d

Ket: a : tipe lurik, b: tipe polos (Betina) ; c: tipe lurik, d:tipe polos (Jantan) Gambar 2. Corak bulu ayam kampung jantan

\section{Frekuensi Kerlip Bulu}

Berdasarkan hasil pengamatan terhadap sifat kualitatif kerlip bulu ayam kampung yang dipelihara di Kecamatan Paguyaman (Tabel 1) ditemukan frekuensi kerlib perak bersifat rersesif terhadap kerlib emas. Hasil ini sama dengan ayam kampung asli dari nunukan memiliki kerlib bulu kemasan sebesar 91-100\%, (Alwi, dkk, S. 2014), sedangkan ayam kampung yang dipelihara di Desa Menaming memiliki frekuensi sebesar 0,620,66 kerlib emas (Sadarman dkk. 2013). Kerlip bulu kurang terlihat pada ayam yang memiliki bulu dengan kombinasi warna yang keragamannya sangat kompleks (Suprijatna et al., 2005).

\section{Frekuensi Warna Kulit Kaki/ Shank}

Berdasarkan hasil pengamatan terhadap sifat kualitatif warna shank (sisik) ayam kampung yang dipelihara di Kecamatan Paguyaman, pada ayam kampung jantan dan betina diperoleh dua macam yaitu putih/ kuning, dan hitam / abu abu (Tabel 6). Sebagian besar warna shank ayam kampung di Kecamatan Paguyaman berwarna kuning/putih $63,66 \%$ atau lebih 50\%, dibandingkan dengan warna hitam/abu-abu (36,34\%). Hal ini sama yang diungkapkan Subekti dan Arlina (2011) melaporkan, frekuensi warna kulit kaki/shank ayam kampung yang dipelihara di Kecamatan Sungai Pagu adalah kuning/putih sebesar $70 \%$ atau lebih 50\% dan warna kulit kaki/shank hitam sebesar $30 \%$

Warna shank Kuning/putih merupakan warna shank yang dominan baik pada ternak jantan maupun pada ternak betina. Warna shank hitam/abuabu bersifat resesif. Hal ini sama dengan hasil penelitian lestari dkk (2020) Warna shank pada ayam kampung dominan warna kuning yaitu sebanyak 16,08\%, diikuti warna putih sebanyak 5,99\% dan hitam sebanyak 2,39\%

Hasil penelitian ini didukung oleh penyataan Dako, et al. (2020) persilangan antara ayam kampung yang memiliki warna shank kuning dikawinkan dengan jenis ayam ras yang memiliki warna shank hitam atau abu-abu, maka keturunan yang dihasilkan memiliki frekuensi warna shank kuning/putih sebesar 70.18-87.32\%. Sifat dominan warna kuning dipengaruhi oleh gen Id yang mampu mengatur melanin pada lapisan dermis untuk menekan pembentukan warna selain kuning.

Warna shank putih disebabkan oleh kurangnya kandungan melanin pada lapisan dermis (albino) dan pengaturan distribusi warna diatur oleh gen. Sartika, dkk (2008) menyatakan bahwa, karakteristik warna cakar kuning atau putih (Id-) disebabkan oleh kurangnya kandungan melanin pada jaringan kulit (dermis). Kandungan melanin dalam lapisan kulit (dermis) dikontrol oleh gen resesif terkait kelamin (id) dalam keadaan homozigot atau heterozigot. Warna cakar hitam Id (inhibitor dari melanin dermis) bersifat dominan tidak lengkap terhadap id.

\section{Frekuensi Bentuk Jengger}

Berdasarkan hasil pengamatan terhadap sifat kualitatif bentuk jengger ayam kampung yang dipelihara di Kecamatan Paguyaman ditemukan empat 
macam bentuk jengger yaitu tunggal, pea, rose, dan walnut. Frekwensi bentuk jengger tunggal $(36 \%)$ dalam penelitian ini, lebih tinggi dibandingkan dengan bentuk jengger pea $(27,82 \%)$, rose (18.51), dan walnut (17.67\%). Berbeda dengan yang dilaporkan Kolompoy, M., dkk (2020) menggambarkan ayam kampung dari Minahasa terdapat 4 jenis bentuk jengger, namun dominasi jengger pea sangat tinggi., sedangkan Lestari dkk, 2020 menyatakan ayam kampung di pulau Lombok memiliki 4 bentuk jengger yaitu Pea (24.46), Rose (8.64), Walnut (36.45) dan Tunggal (30.45). Hasil penelitian ini menggambarkan frekuensi bentuk jengger ayam kampung yang berasal dari kecamatan paguyaman sangat variatif., dengan frekwensi pemunculan tidak saling mendominasi karena frekuensi keempat bentuk jengger yang temukan tidak melebihi 50\%. Variasi bentuk jengger menunjukkan adanya keragaman fenotip bentuk jengger dari ayam kampung. Pertumbuhan jengger pada ayam kampung merupakan salah satu karakter maskulinisasi oleh aktivitas androgen yang menonjol dan paling mudah diamati (Susanti et al 2006).

Frekuensi Gen Ayam Kampung

Frekuensi gen yang dimiliki oleh ayam Kampung yang terdapat di kecamatan paguyaman ditunjukkan pada Tabel 3.

Tabel 3. Frekuensi Gen Ayam Kampung di Kecamatan Paguyaman.

\begin{tabular}{|c|c|c|c|c|}
\hline Sifat & Genotip (Fenotipe) & Alel & Gen & Frekuensi Gen \\
\hline \multirow[t]{2}{*}{ Warna bulu } & I (Tidak berwarna) & I & $\mathrm{qI}$ & 0.04 \\
\hline & Ii (Berwarna) & $\mathrm{i}$ & qi & 0.96 \\
\hline \multirow[t]{3}{*}{ Pola bulu } & E_(Hitam) & $\mathrm{E}$ & $\mathrm{qE}$ & 0.03 \\
\hline & $\mathrm{e}^{+}($Liar $)$ & $\mathrm{e}^{+}$ & $\mathrm{qe}^{+}$ & 0.43 \\
\hline & ee (Columbian) & $\mathrm{e}$ & qe & 0.61 \\
\hline Corak bulu & B_(Polos) & B & $\mathrm{qB}$ & 0.71 \\
\hline (Sex linked) & $\mathrm{Bb}$ (Lurik) & $\mathrm{b}$ & $\mathrm{qb}$ & 0.29 \\
\hline Kerlip bulu & S_(Perak) & $S$ & qS & 0.30 \\
\hline (Sex linked) & ss (Emas) & $\mathrm{s}$ & qs & 0.70 \\
\hline Warna shank & Id (Kuning/ putih) & Id & qId & 0.52 \\
\hline (Sex linked) & id (Abu abu/ hitam) & id & qid & 0.48 \\
\hline \multirow[t]{2}{*}{ Tipe jengger } & $P_{-}($Pea $)$ & $\mathrm{P}$ & $\mathrm{qP}$ & 0.40 \\
\hline & pp (Tunggal) & $\mathrm{p}$ & qp & 0.60 \\
\hline
\end{tabular}

\section{Frekuensi Gen Warna Bulu}

Nilai frekuensi gen warna bulu berwarna pada ayam Kampung di kecamatan Paguyaman menunjukkan nilai lebih tinggi dibandingkan gen warna bulu putih (Tabel 2). Integrasi alel i dalam distribusi warna terhadap gen I sangatlah kuat, hal ini menggambarkan gen I yang membawa sifat warna bulu tidak berwarna (putih) bukanlah gen dominan penuh yang mampu menghambat distribusi pigmen warna didalm sel. Hasil penelitian ini sesuai dengan Nishida et al. (1980) yang menyatakan bahwa ayam Kampung yang diamati di Indonesia memiliki frekuensi gen berwarna lebih tinggi dibandingkan dengan frekuensi gen warna putih. Warna bulu dipengaruhi oleh tiga hal yang terpisah yaitu : warna secara keseluruhan, pola penyebaran warna melalui kontur bulu, dan pola penyebaran warna diantara masing masing bulu (Smyth, 1990).

\section{Frekuensi Gen pola warna bulu}

Nilai frekuensi gen pola warna bulu ayam kampung (Tabel 2) di Kecamatan Paguyaman memiliki frekwensi gen pola bulu Hitam lebih rendah dibandingkan pola liar dan columbian. Gen e, alel e dan alel $\mathrm{e}^{+}$memiliki sifat menghambatan pembentukan warna hitam. Menurut Saleh, dkk, (2020) terbentuknya pola warna bulu disebabkan interaksi alel yang mengatur pigmen dan interaksi hambatan melamin dan eumelamin dalam melanocity, interaksi sifat hambatan terhadap gen $\mathrm{E}$ terlihat adanya frekuensi 
frekuensi alel e dan $\mathrm{e}^{+}$di lokus E yang tinggi., sedangkan (Crawford, D. S. 1990) Alel warna coklat/coklat muda $\left(\mathrm{e}^{\mathrm{b}}\right)$ adalah mutasi dari gen $\mathrm{E}$ di lokus $\mathrm{E}$ dan saling berinterakasi bersama alel ee di lokus $\mathrm{E}$ sehingga mengahasilkan warna coklat. Gen dan alel pola warna bulu ini bersifat poygenik (Park, dkk, 2013)

\section{Frekuensi Gen Corak Bulu}

Frekuensi gen corak bulu lurik dari ayam kampung di Kecamatan Paguyaman memiliki nilai 0,71 dan polos (0.29). Gen lurik dominan disebabkan adanya perkawinan ayam lokal dengan ayam yang berasal dari bangsa lain. Nishida et al. (1980) menyatakan bahwa gen yang terdapat pada Barred Plymouth Rock adalah $\mathrm{Bb}$ (corak bulu lurik).

\section{Frekuensi Gen Kerlip Bulu}

Frekuensi gen kerlip bulu keemasan pada ayam Kampung di Kecamatan Paguyaman lebih tinggi (Tabel 2) dibandingkan dengan kerlip keperakan. Hal ini tidak berbeda dengan Hasil penelitian Sadarman $d k k$. (2013) melaporkan bahwa kerlip bulu ayam kampung yang dipelihara di Desa Menaming frekuensi tertinggi baik jantan maupun betina adalah kerlip bulu emas yaitu 0,66 untuk ternak jantan dan 0,62 untuk ternak betina. Frekuensi gen kerlip keperakan lebih tinggi dikarenakan adanya gen $S$ (kerlip keperakan) pada ayam.

\section{Frekuensi Gen Warna Shank}

Berdasarkan tabel 2 Frekuensi gen warna shank kuning dominan terhadap warna shank hitam/abu-abu.Warna shank kuning yang dominan karena selama penelitian lebih banyak di temukan ayam kampung yang memiliki warna shank kuning. Dugaan penyebab tingginya frekuensi gen pada ayam kampung dibutuhkan informasi yang lebih banyak, terutama dilakukan uji keturunan, apakah disebabkan adanya aliran gen asing yang

\section{DAFTAR PUSTAKA}

Alwi, M., Sumantri, C., \& Darwati, S. (2014). Karakteristik Genetik dan mempengaruhi atau tidak. Menurut Dako, et al (2020) perkawinanan antara ayam kampung (shank kuning) dan ayam ras (shank kuning) dan ayam hybro (shank puyih) secara triple crossing menghasilkan ayam silangan yang memiliki shank kunig (dominan). Warna shank kuning/putih juga dapat diduga merupakan hasil dari keturunan ayam Hutan Hijau yang merupakan salah satu ayam hutan yang ada di Indonesia. Ayam hutan yang menyebar di Indonesia yaitu ayam Hutan Merah (Gallus gallus) dan ayam Hutan Hijau (Gallus Varius) dimana ayam Hutan Hijau memiliki ciri spesifik yaitu kaki kekuningan (Sartika, 2008).

\section{Frekuensi Gen Bentuk Jengger}

Frekuensi gen bentuk jengger Ayam kampung di kecamatan paguyaman, adalah pp sebesar 0.60 (berbentuk tunggal) dan P- sebesar 0.40 (berbentuk Pea). Hasil penelitian ini berbeda hasil yang diungkapkan oleh Nishida et al. (1980) menyatakan bahwa ayam Kampung memiliki frekuensi gen jengger pea yang lebih tinggi dibandingkan jengger tunggal yang diamati di Indonesia.

\section{KESIMPULAN}

Frekuensi fenotipe Ayam Kampung di Kecamatan Paguyaman, Kabupaten Boalemo, Propinsi Gorontalo memiliki sifat kualitatif yang beragam, baik berdasarkan pada frekuensi fenotipe maupun frekuensi gen. Frekuensi fenotipe yang paling banyak ditemukan adalah warna bulu berwarna, pola warna bulu liar, corak lurik, kerlip bulu emas, warna shank kuning/putih, dan bentuk jengger tunggal. Frekuensi gen yang paling banyak ditemukan adalah gen i (warna bulu berwarna), ee (pola bulu Columbian), B (corak bulu polos), s (kerlip bulu emas), Id (warna shank kuning/putih), dan $p$ (tipe jengger tunggal), dengan genotype $: q^{i i_{-} e B I d_{-} p p}$

Fenotip Ayam Nunukan di Pulau Tarakan, Kalimantan Timur. 
Bugiwati, S. R. A., Syakir, A., \& Dagong, M. I. A. (2020, April). Phenotype characteristics of Gaga chicken from Sidrap regency, South Sulawesi. In IOP Conference Series: Earth and Environmental Science (Vol. 492, No. 1, p. 012103). IOP Publishing.

Crawford, D. S. 1990. Poultry Breeding and Genetics. Elsevier. Amsterdam.

Dako, S. 2013. Kelenturan Fenotipik SifatSifat Produksi Dan Reproduksi Burung Puyuh Yang Di Beri Kadar Garam Berbeda Dalam Air Minum. Tesis. Universitas Sam Ratulangi. Manado

Dako, S. (2019). Crossbreding Between Native Chiken And Leghorn Chiken Strain Isa Brown. Jurnal Peternakan, 16(1), 1-9.

Dako, S., Ilham, F., Laya, N. K., \& Yusuf, M. F. (2019). Manajemen pembibitan Ternak. Buku Ajar, Publisher Arthasamudra ISBN, 978-623.

Dako, S., Ilham, F., Laya, N. K., \& Yusuf, F. M. (2020). Nheritance of external genetic characteristics in chicken through triple crossing model. International Journal of Advanced Science and Technology, 29 (9 Special Issue), 549-558. http://sersc.org/journals/index.php LIJAST/article/view/13134

Edowai, E., Tumbal, E. L. S., \& Maker, F. M. (2019). Penampilan Sifat Kualitatif Dan Kuantitatif Ayam Kampung Di Distrik Nabire Kabupaten Nabire. Jurnal FAPERTANAK: Jurnal Pertanian dan Peternakan, 4(1), 50-57

Kolompoy, M., Lambey, L. J., Paputungan, U., \& Tangkere, E. S. (2020). Keragaman Sifat Kualitatif Ayam Kampung Di Minahasa. ZOOTEC, 40(2), 580-592.
Lestari, L., Maskur, M., Jan, R., Rozi, T., Kasip, L. M., \& Muhsinin, M. (2020). Studi Karakteristik Sifat Kualitatif Dan Morfometrik Induk Ayam Kampung Dengan Berbagai Tipe Jengger Di Pulau Lombok. Jurnal Ilmu dan Teknologi Peternakan Indonesia (JITPI), Indonesian Journal of Animal Science and Technology, 6(1), 24-32

Mansjoer, S.S. 2005. Pengkajian sifat-sifat produksi ayam kampung serta persilangannya dengan ayam rhode island red. Disertasi. Program Pasca Sarjana Institut Pertanian Bogor, Bogor.

Nishida, T., K. Nozawa, K. Kondo, S. S. Mansjoer and H. Martojo. 1980. Morphological and genetical studies in the Indonesian native fowl. The Origin and Phylogeny of Indonesian Native Livestock. I:47-70.

Park, M. N., Choi, J. A., Lee, K. T., Lee, H. J., Choi, B. H., Kim, H.,\& Lee, T. (2013). Genome-wide association study of chicken plumage pigmentation. Asian-Australasian journal of animal sciences, 26(11), 1523.

Rafian, T., Jakaria, J., \& Ulupi, N. (2017). Keragaman Fenotipe Sifat Kualitatif Ayam Burgo di Provinsi Bengkulu. Jurnal Sain Peternakan Indonesia, 12(1), 47-54.

Noor R.R. 2008. Genetika Ternak, Penebar Swadaya.

Masili, S., Dako, S., Ilham, F., \& Gubali, I. S. (2018). Heritabilitas Bobot Telur, Bobot Tetas Dan Bobot Badan Ayam Hasil Persilangan Umur 1 Minggu (DOC). Jambura Journal of Animal Science, 1(1), 1-5.

Safriyanto Dako, Fahrul Ilham, Nibras. K. Laya, Frida. M Yusuf. (2020). 
NHERITANCE OF EXTERNAL GENETIC CHARACTERISTICS IN CHICKEN THROUGH TRIPLE CROSSING MODEL. International Journal of Advanced Science and Technology, 29(9s), 549-558. Retrieved from

http://sersc.org/journals/index.php /IJAST/article/view/13134

Saleh, U. (2020). Keseimbangan Genetik Eksternal pada Ayam Hasil Silangan. Jambura Journal of Animal Science, 2(2), 76-89

Sartika T., DK. Wati, HS. Rahayu, dan S. Iskandar. 2008. Perbandingan genetik eksternal ayam wareng dan ayam kampung yang dilihat dari laju introgresi dan variabilitas genetiknya. JITV, 13(4): 279-287.

Scanes, C. G., G. Brant \& M. E. Ensminger. 2004. Poultry Science. Pearson Education Inc., New Jersey.

Subekti, K., \& Arlina, F. (2011). Karakteristik genetik eksternal ayam kampung di kecamatan sungai pagu kabupaten solok selatan. Jurnal Ilmiah Ilmu-Ilmu Peternakan, 14(2), 74-86.

Sudarman, Elfawati dan Sadriad. 2013, Studi frekuensi sifat kualitatif ayam kampung Di desa menaming kecamatan rambah Kabupaten rokan hulu provinsi riau. (Skripsi) Fakultas Pertanian dan Peternakan Universitas Islam Negeri Sultan Syarif Kasim. Riau.

Sumantri, C., Khaerunnisa, I., \& Gunawan, A. (2020, April). The genetic quality improvement of native and local chickens to increase production and meat quality in order to build the Indonesian chicken industry. In IOP Conference Series: Earth and Environmental Science (Vol. 492, No. 1, p. 012099). IOP Publishing.

Suprijatna, E. U., Atmomarsono dan R. Kartasudjana, 2005. Ilmu Dasar tenak Unggas. Penebar Swadaya. Jakarta 